\title{
The Effect of Leverage on Corporate Cash Holdings: Evidence from Indonesian Manufacturing Firms
}

\author{
Anggita Langgeng Wijaya ${ }^{1}$, Bandi ${ }^{2}$ \\ ${ }^{1}$ PDIE Student of Universitas Sebelas Maret \\ Faculty of Economics and Business, Universitas PGRI Madiun \\ Kota Madiun, Indonesia \\ Email: Gonggeng14@gmail.com \\ ${ }^{2}$ Faculty of Economics and Business, Universitas Sebelas Maret \\ Kota Surakarta, Indonesia \\ Email: bandi.ssm@gmail.com
}

\begin{abstract}
The objective of this research is to test the impact of leverage on corporate cash holdings for sample of manufacturing companies enlisted on the Indonesian Stock Exchange over the period 2006-2007. Population of this research is all of manufacturing companies on the Indonesian Stock Exchange. The sampling method is purposive. The study hypothesis was tested using multiple regressions. The results show that leverage has a negative influence on corporate cash holdings. Indonesian manufacturing firms with high leverage can hold cash in small amounts because debt is a substitute for corporate cash holdings.
\end{abstract}

Keyword: leverage, cash holdings, financing, risk, Indonesian manufacturing firms

JEL code: G32

\section{Introduction}

Based on Soltani and Ravanmehr (2011), the financial management literature speaks about the importance of company resource management. Cash is an important resource in the behavior of company financial management. The company financial strategy becomes important to be researched especially related to its use, whether it is distributed to cash holder, spent for internal purposes, used to do acquisition or held in to cash holding. According to Teruel et al. (2009), cash holding is a ratio that compares the amount of cash and cash equivalents with total assets of the company. Afza and Adnan (2007) stated that decisions of corporate cash holdings are affected by the company's financial policies such as capital structure policy, working capital management, cash flow management, dividend and investment decisions.

Ginglinger and Saddour (2008) claimed that cash holdings are used for some important decisions in the company, such as distributed to share holders in the form of dividends, stock repurchases, investment decisions, or saved for something important in the future. Companies must be able to keep cash on the importance optimal level, because holding too much cash in the assets is unproductive and means high cost. Jani et al. (2004) stated that in a perfect capital market, cash 
holdings are irrelevant because a company can easily obtain financial resources at any time and at the same rate. In market conditions with asymmetric information, agency costs and transaction costs, cash holdings will be important. Explanation about cash holding raises two theories; the trade-off theory (TOT), and the pecking order theory (POT). According to the trade-off theory, the companies try to reach an optimal level of cash holding with respect to trade-off between the costs and benefits of having cash holding. According to the pecking order theory, the motivation of companies to have a cash holding is management's policy on the company's funding sources. Company funding sources can be obtained from internal sources and external funding sources. Companies prefer to use internal funds to external funding.

The study aims to examine the effect of leverage on cash holdings on the Indonesian Stock Exchange. The evidence from previous studies about cash holdings has gained inconclusive results. Gill and Shah (2012) explained that research about corporate cash holdings is still required in order to give explanation about company's motivation to get cash holding. According to Wenyao (2007), leverage is one of several factors that determine corporate cash holdings. Leverage is a ratio that compares the total debts with total assets of companies. Leverage indicates the company's ability to issue debt, so that the possible effect on cash holding leverage is negative.

The opposite opinion was expressed by Guney et al. (2007). Guney et al. (2007) stated that firms with high leverage have a tendency to financial constraints, so that they will try to increase the cash holdings. The companies with high leverage will hold much cash in order to meet the financing policy and avoid financial distress. Borhanuddin and Ching (2011) mentioned that cash holdings are internal financial resources. Leverage and corporate cash holdings have a negative relationship. Leverage and cash holdings are substitutes. If the company already has a strong internal financial resources it does not need to take funds from external sources. One result of this study was that leverage negatively affects corporate cash holding.

An opposite opinion was expressed by Ferreira and Vilela (2003), who stated that leverage has a positive effect on cash holding companies. A large amount of leverage is a potential bankruptcy for the company, so if the company has a large leverage it should have corporate cash holdings in an amount sufficient to cover potential bankruptcy. Ozkan and Ozkan (2004) conducted an empirical investigation about the cash holding companies in the United Kingdom. The data for the study were taken from the Data Stream database. One result of this study has shown that leverage gives a negative effect on the company cash holding. It is contradictory to the financial constraint hypothesis by Ginglinger and Saddour (2008), who mentioned that leverage has a positive effect on corporate cash holdings. 
Based on the observations above, there are several contradictory results from previous research as regards the effects of leverage on cash holdings. This motivates the researchers to reexamine the effect of leverage on corporate cash holdings by taking a sample of manufacturing firms on the Indonesia stock exchange. This research was only carried out in the manufacturing industry because thus the researchers avoided the bias in the study results caused by differences in company characteristics. Other industries such as financial services and banking have special characteristics related to certain standards set by the Indonesian regulator. The manufacturing industry was chosen as a sample because of the consideration of the number of samples that can be obtained. In addition, the researchers assessed the cash conversion cycle in manufacturing companies relatively longer because they had to change raw materials into finished goods so that research on cash holding companies was interesting.

This study uses cash flow, firm size and return on assets as control variables. Wenyao (2007) explained that companies with high operating cash flows will tend to hold large amounts of cash, because companies prefer internal funding sources. Saddour (2006) explained that the relationship between firm size and cash holding is positive. Large companies have a high operational level of cash flow and a small level of information asymmetry, so companies can easily increase their cash. ROA shows the company's ability to produce earnings. The ability to generate profits is also expected to be balanced with the ability to convert profits into cash, so that high ROA is expected to be directly proportional to the company's cash holdings.

The analysis is interesting because the results of this study are expected to provide investors an overview about the condition of the cash holdings of manufacturing companies in Indonesia. By considering the relationship between leverage and cash holdings, investors are expected to be able to assess whether a company is holding too much cash or not. If the company's cash holdings are considered too high, investors can advise management to use the cash in other activities that are more productive and able to increase earnings. The increase in company earnings is expected to provide additional firm value. If investors assess the condition of cash holdings as too small, investors can advise management to increase cash to avoid financial distress.

\section{Literature Review and Hypothesis Development}

Ginglinger and Saddour (2008) said that corporate cash holding is the amount of cash held to finance various activities of a company. According to Keynes (1937), the benefits of cash holdings can be analyzed in terms of the transaction, the precaution, and the speculation motives. The transaction motive, according to this theory, is when the company holds cash to finance various corporate transactions. If the company can easily get funds from the capital markets, holding cash is not required; if not, the company needs cash holdings to finance the transactions. If there is information asymmetry and high agency cost of debt, it will cause that external funding will also be higher, which causes the amount of cash holdings also 
become greater (Keynes, 1937). The precaution motive means that corporate cash holdings are used to anticipate unexpected events from the aspect of financing especially in the countries with unstable economy system. Capital markets will be affected by the macroeconomic conditions such as changes in exchange rates, which may affect the value of corporate debt of a company. It causes that a company needs cash holding to anticipate the possibility of a bad economic condition. The speculation motive in this theory means that the company will use the cash to speculatively observe a variety of new business opportunities that are considered favorable. Growing companies can make acquisitions of other companies that require large amounts of cash. The arbitrage motive, as this theory states, is that firms hold cash to take advantage of the many policy differences between countries. Companies can take funds from foreign capital markets with a lower interest rate, then through trade mechanisms invest such funds in domestic capital markets that have a higher interest rate.

Koshio (2003) stated that corporate cash holdings in the capital markets can be seen from two approaches, The trade-off view of cash holdings and Financing Hierarchy View of cash holdings. The trade-off view of cash holdings says that company cash holdings may be actively managed by the trade-off between the costs and benefits. By equaling the marginal costs to marginal benefits of holding cash, the decision leads to optimal levels of cash holdings, consistent with the shareholder value maximization objective. Koshio (2003) also introduced a view point related to company cash holding called the Financing Hierarchy View. Based on this theory, a firm needs cash holding because of the need for internal financial resources, if it is not adequate, the second option is issuing debt, and the third is issuing new equity in which the cost of issue will be more expensive. Afza and Adnan (2007) stated that the financial manager should cash at sufficient portion for the purposes of reinvestment policy to distribute to investors and keep cash in the company. Based on the trade-off theory, firms draw up cash to an optimal level by considering the marginal costs and benefit of holding cash. Cash holdings provide several benefits for the company. Cash holdings can be used as a reserve fund if the company faces financial distress. Cash holdings can maximize a company's investment policy, especially if the company has difficult access to external funding sources (Afza and Adnan, 2007).

Ginglinger and Saddour (2008) said that there are two opinions relating to the relationship of leverage and cash holding in a company. First, firms with high leverage have a higher tendency of financial constraints as well as companies faced with the high cost of external financing (Guney et al., 2007). Schwetzler and Reimund (2004) stated that the level of cash holdings related to the valuation of liquidity assets. This study states that one of the motivations of holding cash is a short-term debt of the company. This opinion is in line with Ginglinger and Saddour (2008), who stated that one of the company's motivations for having the cash holdings is financial constraint hypothesis. Companies with high financial constraints have a tendency to hold higher cash. This raises a presumption that 
leverage as a proxy for financial constraints is positively related to cash holdings. Second, the opinions stated that leverage negatively affects cash holding. Ozkan and Ozkan (2004) mentioned that leverage is negatively related to corporate cash holdings. Debt is a substitution for the cash holdings, so that if the company has a high level of leverage, it may hold cash holding at a low level.

Ozkan and Ozkan (2004) stated that several studies had tried to give an explanation of the reason why companies have cash holdings. One reason appears to be that cash provides a lower cost of funding. Information asymmetry between management and investors will cause expensive external funding costs. Expensive external funding will cause companies to spend more funds to finance these external funding sources. This condition will lead the company to greater operational risk. Information asymmetry will also have an impact on higher agency costs (Jensen, 1986). Based on the explanation above, company managers try to minimize the costs associated with external funding. If the conditions of the capital market are not perfect, of course, external financial resources are expensive. On the other hand, company managers want to reduce risk and have flexibility in using internal funds (Jensen, 1986). Furthermore, Ozkan and Ozkan (2004) revealed that there is a negative aspect of corporate cash holdings. This view states that the agency conflict between managers and shareholders will be greater, especially if the company has free cash flow in large numbers. According to Jensen (1986), some opportunistic managers are more concerned with their own interests by using cash to meet their own interests rather than focusing on the interests of shareholders.

The results of Ginglinger and Saddour (2008) suggest that research into cash holdings gives different results when comparing developed countries and developing countries. In developing countries, companies face a major financial constraint and weak protection of shareholder rights. This results in the companies having a tendency to have a large cash holding. In developed countries, large companies tend to have fewer financial constraints, have a good quality of governance as well as easy access to the capital markets so that companies tend to hold cash holdings in small values. According to Teruel et al. (2009), the relation between leverage and cash holdings is negative. This is because if the company has good access to the bond market, it can use debt as a current asset substitution, despite the fact that the company would rather have a high cash and low debt. Companies with high debt will use debt to invest that the amount of cash held is smaller. The results of Ozkan and Ozkan (2004) showed evidence that if leverage increases, the amount of cash holding will decline.

Guney et al. (2007) conducted a study on the relationship between leverage and corporate cash holding. The research was conducted internationally by performing comparisons between countries, France, Germany, Japan, United Stated of America and United Kingdom. The relationship between leverage and cash holding can be positive or negative. If leverage is the substitution of cash that can be used by companies to investment decision, the relationship between leverage and cash 
holdings is negative. However, due to the large amount of leverage, the company will accumulate large amounts of cash to reduce the risk of financial distress and bankruptcy so that the relationship between leverage and cash holding is positive.

Ozkan and Ozkan (2004) conducted an empirical investigation about the cash holding companies in the UK. Data used in the study were taken from the Data Stream Database. One result of this study stated that leverage negatively affects corporate cash holdings. This result contradicts the hypothesis of financial constraints (leverage as a proxy for financial constraints) expressed by Ginglinger and Saddour (2008), who stated that leverage has a positive influence on corporate cash holdings. Alvarez et al. (2010) conducted a study on the crisis of liquidity and cash holding in Chile. The study was conducted with data from 1986 to 2009, the Chilean Super intendancy of Securities and Insurance (SVS). The results of this study confirmed the results of research conducted by Ozkan and Ozkan (2004), who found a negative relationship between leverage and corporate cash holdings. The underlying reason is that the increased leverage of the company is a substitution of the use of cash for investments. Companies can use debt to finance investments so that they do not need to hold large amounts of cash because of the ease of access to sources of funding.

Wenyao (2007) conducted research into several factors that affect cash holdings in companies listed on the Shanghai Stock Exchange (SHSE) and the Shenzhen Stock Exchange (SZSE) in China. According to this study, the relationship between leverage and cash holding can be positive and negative. If leverage is the substitution for the need for investment funds, increased leverage will cause a small amount of cash holdings, so that the relationship between leverage and cash holdings is negative. However, when seen from the side of the agency costs of debt and the potential for financial distress and bankruptcy, the relationship between leverage and cash holdings is positive. Companies with large debts will tend to have large cash holdings to pay off the debt (Wenyao, 2007). The second opinion from Wenyao (2007) supported the idea of Guney et al.(2007) and Opler et al. (1999), who stated that leverage has a positive effect on corporate cash holdings.

Couderc (2005) stated that leverage effect on cash holdings is negative. High ratio of leverage indicates the ease of access to the capital market, so that companies can hold a small amount of cash. Saddour (2006) stated that the effects of leverage on cash holding are negative. This is because debt can be used to finance various investments of the companies. According to Saddour (2006), debt is a substitute of cash that can be used to finance the company's investment. Companies that have a high amount of debt can hold cash in small amounts. This opinion is consistent with the opinion of Couderc (2005).

Jani et al. (2004) stated that the relationship between leverage and cash holding can be explained using two approaches: the trade-off theory (TOT) and the pecking order theory (POT). From the perspective of the trade-off theory (TOT), holding too much cash balances is unproductive for the company. Leverage is the substitution 
of cash that can be used to finance the company's activities so that the relationship between the cash and leverage is negative. Ozkan and Ozkan (2004) stated that the debt would reduce the moral hazard issue. Debt is more flexible and easier to be renegotiated if there are difficulties for the company. Debt is the substitution of cash holdings so the relationship between leverage and cash holdings is negative (Ozkan and Ozkan, 2004).

From the perspective of the pecking order theory (POT), Jani et al. (2004) explained that the relationship between cash holdings and leverage is positive. Companies with sufficient financial resources will be using cash for operating activities of the company. If internal resources are not sufficient, the company will use debt. The company will seek to establish the optimal debt. When debt reaches maturity, the company needs cash to pay off the debt, so companies with high level of leverage will require large amounts of cash. The relationship between leverage and cash holdings is positive (Jani et al., 2004).

Based on the discussion above, the hypothesis proposed in this study is as follows.

Hypothesis 1: Leverage has a significant influence on corporate cash holdings.

\section{Research Methods}

\subsection{Data, Population and Sample}

The population of this research is all of manufacturing companies listed on the Indonesia Stock Exchange. This study uses secondary data from financial statements of manufacturing companies over period 2006-2007. The data in this study were taken by the purposive sampling method. From the obtained data collecting samples there are 112 companies in every year, so the number of observations over two years is 224 companies.

\subsection{Definition and Operational of Variables}

\section{Dependent variable}

Teruel et al. (2009) said that corporate cash holding is a financial ratio that compares the amount of cash in a company with total assets. Referring to Teruel et al. (2009), holding cash is calculated by the following formula.

$$
\text { Cash Holding }=\frac{\text { Total Cash }+ \text { Equivale }}{\text { Total Assets-Cash }}
$$

\section{Independent variables}

The independent variable in this study is leverage. Leverage is a financial ratio that compares the total debt to total assets of the company. Referring to Wenyao (2007), leverage is calculated by the following formula.

$$
\text { Leverage }=\frac{\text { Total debt }}{\text { Total Ass }}
$$




\section{Variable Control}

There are three control variables used in this study including cash flow from operations (CFO) measured by operating cash flow divided by total assets of the company, size of company (LNSZE) measured by the natural logarithm of total assets of the company and the company's profitability measured by return on assets compared between net income and total assets.

\subsection{Data Analysis Method}

The hypothesis in this study is tested with multiple regressions, while the regression equation used in this study is:

Cash $=\alpha+\beta_{1} L E V+\beta_{2} R O A+\beta_{3} C F O+\beta_{4} \ln S I Z E+\varepsilon$

where: CASH: corporate cash holdings, LEV: leverage, ROA: return on assets, CFO: Operating cash flow, LNZISE: firm size. Prior to the regression test, the descriptive statistics are tested as well as classic assumptions that include normality test data, auto correlation test, multicolinearity test and test of heteroscedasticity.

\section{Results}

\subsection{Descriptive Statistics}

This study is aimed to examine the effect of leverage on cash holding in manufacturing companies listed on the Indonesia Stock Exchange in 2006-2007. The results of the data collection as the number of observations obtained are about 224 companies. Researchers get as much as 49 samples so that the amount of data outlier observations used is about 175 companies. The test results of the descriptive statistics and correlations among the independent variables are presented in the following table.

Table 1 Descriptive statistic

\begin{tabular}{lccccc}
\hline \multicolumn{1}{c}{ Variable } & N & Min & Max & Mean & Std. Deviation \\
\hline \hline LEV & 175 & 0.07 & 2.98 & 0.6509 & 0.43744 \\
\hline CFO & 175 & -0.33 & 0.51 & 0.0434 & 0.11075 \\
\hline ROA & 175 & -0.22 & 0.37 & 0.0284 & 0.07118 \\
\hline LNSIZE & 175 & 23.91 & 31.78 & 27.2035 & 1.46789 \\
\hline CASHHOLD & 175 & 0.00 & 0.28 & 0.0494 & 0.04875 \\
\hline
\end{tabular}

Source: Author's calculation.

Table 1 shows the results of the descriptive statistics test. They show that the average sample firm has cash holdings of $4.9 \%$ and an average leverage of $65.09 \%$. Control variable had an average ratio of operating cash flow amounting to $4.3 \%$, the average profitability of $2.8 \%$ and average firm size (log natural of total assets) of 27.20. Table 2 shows the correlations among the independent variables. The greatest correlation occurs between profitability (ROA) and cash holdings - 
$45 \%$, the smallest correlation occurs between firm size (LNSIZE) and cash holdings $-7.9 \%$.

Table 2 Correlation

\begin{tabular}{|c|c|c|c|c|c|}
\hline Variable & CASHHOLD & LEV & ROA & CFO & LNSIZE \\
\hline & 1 & $-0.226(* *)$ & $0.450(* *)$ & $0.395(* *)$ & 0.079 \\
\hline \multirow[t]{3}{*}{ CASHHOLD } & & 0.003 & 0.000 & 0.000 & 0.298 \\
\hline & 175 & 175 & 175 & 175 & 175 \\
\hline & $-0.226(* *)$ & 1 & $-0.218(* *)$ & -0.089 & -0.138 \\
\hline \multirow[t]{3}{*}{ LEV } & 0.003 & & 0.004 & 0.242 & 0.069 \\
\hline & 175 & 175 & 175 & 175 & 175 \\
\hline & $0.450(* *)$ & $-0.218(* *)$ & 1 & $0.429(* *)$ & $0.259(* *)$ \\
\hline \multirow[t]{3}{*}{ ROA } & 0.000 & 0.004 & & 0.000 & 0.001 \\
\hline & 175 & 175 & 175 & 175 & 175 \\
\hline & $0.395(* *)$ & -0.089 & $0.429(* *)$ & 1 & $0.291(* *)$ \\
\hline \multirow[t]{3}{*}{ CFO } & 0.000 & 0.242 & 0.000 & & 0.000 \\
\hline & 175 & 175 & 175 & 175 & 175 \\
\hline & 0.079 & -0.138 & $0.259(* *)$ & $0.291(* *)$ & 1 \\
\hline \multirow[t]{2}{*}{ LNSIZE } & 0.298 & 0.069 & 0.001 & 0.000 & \\
\hline & 175 & 175 & 175 & 175 & 175 \\
\hline
\end{tabular}

Source: Author's calculation.

\subsection{Regression Test Results}

Regression test results in this study are presented in the following table.

Table 3 Regression

\begin{tabular}{|c|c|c|c|c|c|c|}
\hline \multirow[t]{2}{*}{ Model } & \multirow[t]{2}{*}{ Variable } & \multicolumn{2}{|c|}{$\begin{array}{l}\text { Unstandardized } \\
\text { Coefficients }\end{array}$} & \multirow{2}{*}{$\begin{array}{c}\begin{array}{c}\text { Standardized } \\
\text { Coefficients }\end{array} \\
\text { Beta }\end{array}$} & \multirow[t]{2}{*}{$\mathbf{t}$} & \multirow[t]{2}{*}{ Sig. } \\
\hline & & B & $\begin{array}{l}\text { Std. } \\
\text { Error }\end{array}$ & & & \\
\hline & (Constant) & 0.143 & 0.063 & & 2.279 & 0.024 \\
\hline \multirow[t]{4}{*}{1} & LEV & -0.016 & 0.007 & -0.145 & -2.161 & 0.032 \\
\hline & ROA & 0.225 & 0.051 & 0.329 & 4.430 & 0.000 \\
\hline & CFO & 0.119 & 0.032 & 0.271 & 3.685 & 0.000 \\
\hline & LNSIZE & -0.003 & 0.002 & -0.105 & -1.515 & 0.132 \\
\hline
\end{tabular}

\begin{tabular}{ll}
\hline R Square & $: 0.270$ \\
Adj. R Square & $: 0.263$ \\
F Value & $: 16.48$ \\
Prop F & $: 0.000$ \\
\hline
\end{tabular}

Source: Author's calculation.

The test results of the regression model show a value of the coefficient of determination of 0.263 . This means that $26.3 \%$ change of corporate cash holding 
can be explained by leverage, return on assets, operating cash flows and firm size. Test on the value of $F$ regression coefficient is at 16.48 with a probability value of 0.000 . $F$ value of regression testing showed significant results, this means that the model fits between the data and the model tested.

The hypothesis in this study aims to examine the effect of leverage on corporate cash holdings. The test results are -0.016 regression coefficients with $p$ value of 0.032 . The results of the regression test showed a negative regression coefficient, so the researchers concluded that the effect of leverage on corporate cash holdings is negative. The results of this study support research performed by Ozkan and Ozkan (2004), which stated that leverage negatively affects corporate cash holdings. The results support the view held by Jani et al. (2004), who explained using the trade-off theory that the relationship between leverage and corporate cash holdings is negative.

The results of this study indicate that leverage has a negative effect on cash holdings within manufacturing companies in Indonesia. This further indicates that manufacturing companies in Indonesia have good access to funding sources, so there is no need to hold large amounts of cash. Average sample companies only hold cash of around $4.9 \%$, which means manufacturing companies in Indonesia maintain cash at a small level. Naturally, this result is good information for investors because if a company holds cash in large amounts on the balance sheet, it is unproductive. Debt is a substitution for corporate cash holding. Corporate debt indicates an easy access to funding sources. Companies with large debts can hold small amounts of cash (Ozkan and Ozkan, 2004).

The test results of the control variables indicate that the return on assets and operating cash flow have a positive effect on cash holding while the size of the company does not have a significant effect on corporate cash holdings. The results of this study indicate a positive effect between profitability and cash flow from operations to corporate cash holdings. Companies with high profitability and high cash flows from operations have a tendency to hold high cash in large amounts.

\section{Conclusion}

This study investigates the effect of leverage on corporate cash holdings. Based on the data analysis, it can be concluded that the leverage has a negative effect on corporate cash holdings. The results of this study indicate that an average Indonesian manufacturing company holds cash in small amounts. The negative effect of leverage on cash holdings shows that manufacturing companies in Indonesia have good access to funding sources. The ability to obtain debt can be used as a substitute for the company's cash needs. Manufacturing companies in Indonesia are proven not to use cash holding for actions that harm shareholder value. Investors only need to monitor and ensure that the cash level held by the company is sufficient in amount so that the company can continue to carry out its operational activities and avoid financial distress. 
The test results of the control variables indicate that the return on assets and cash flow from operations has positive effect on corporate cash holdings while firm size does not affect corporate cash holdings. Investors can look at the conditions of return on assets and cash flow as an effort to maintain the availability of cash holdings of the company. If investors find that return on assets and cash flow are declining, investors can remind the company management about the adequacy of cash holdings.

This study is not free from some limitations. Limitations of this study include a relatively short period of study, as only the period 2006-2007 was investigated. The research was only conducted into manufacturing companies so the research results are not generalizable. Future research is recommended to test the other factors thought to influence the corporate cash holdings as corporate governance and accounting conservatism.

\section{References}

Afza, T. and Adnan, M. (2007). Determinants of Corporate Cash Holdings: A Case Study of Pakistan. In: Proceedings of Singapore Economic Review Conference (SERC).

Alvarez, R., Sagner, A. and Valdivia, C. (2010). Liquidity Crises and Corporate Cash Holdings in Chile. Working Papers Central Bank of Chile 564, Central Bank of Chile.

Borhanuddin, R.I. and Ching, P.W. (2011). Cash Holdings, Leverage, Ownership Concentration and Board Independence: Evidence from Malaysia. Malaysian Accounting Review, 10(1), pp. 63-88.

Couderc, N. (2005). Corporate Cash Holdings: Financial Determinants and Consequences. Available at: https://www.efmaefm.org/OEFMSYMPOSIUM/ 2005/papers/09-Nicolas_Couderc_paper.pdf.

Ferreira, M.A. and Vilela, A.S. (2011). Why Do Firms Hold Cash? Evidence from EMU Countries. European Financial Management, 10(2), pp. 295-319.

Gill, A. and Shah, C. (2012). Determinants of Corporate Cash Holdings: Evidence from Canada. International Journal of Economics and Finance, 4(1), pp. 70-79.

Ginglinger, E. and Saddour, K. (2008). Cash Holdings, Corporate Governance and Financial Constraints. Available at: https://papers.ssrn.com/sol3/papers.cfm? abstract_id=1188843.

Guney, Y., Ozkan, A., and Ozkan, N. (2007). International Evidence on the NonLlinear Impact of Leverage on Corporate Cash Holdings. Journal of Multinational Financial Management, 17(1), pp. 45-60.

Jani, E., Hoesli, M. and Bender, A. (2004). Corporate Cash Holdings and Agency Conflicts. Available at: https://papers.ssrn.com/sol3/papers.cfm?abstract_id $=563863$.

Keynes, J.M. (1937). The General Theory of Employment. Quarterly Journal of Economic, 52(2), pp. 209-233. 
Koshio, S. (2003). The Determinants of Corporate Cash Holdings in Brazil. Research Plan for PhD Dissertation Fundação Getúlio Vargas - EAESP, Brazil.

Opler, T.L., Pinkowitz, Stulz, R. and Williamson, R. (1999). The Determinants and Implications of Corporate Cash Holdings. Journal of Financial Economics, 52(1), pp. 3-46.

Ozkan, A. and Ozkan, N. (2004). Corporate Cash Holdings: An Empirical Investigation of UK Companies. Journal of Banking and Finance, 28(9), pp. 21032134.

Saddour, K. (2006). The Determinants and the Value of Cash Holdings: Evidence from French firms. Available at: http://www.finance.dauphine.fr/wpcontent/uploads/sites/3/2015/07/cereg200606.pdf.

Schwetzler, B. and Reimund, C. (2004). Valuation Effects of Corporate Cash Holdings: Evidence from Germany. Available from: https://papers.ssrn.com/sol3/papers.cfm?abstract_id=490262

Soltani, A. and Ravanmehr, N. (2011). Corporate Governance, Ownership Concentration, Cash Holdings and Firm Value on The Tehran Stock Exchange. Interdisciplinary Journal of Contemporary Research in Business, 3(6), pp. 47-55.

Teruel, P.J.G., Solano, P.M. and Ballesta, J.P.S. (2009). Accruals Quality and Corporate Cash Holdings. Journal Compilation Accounting and Finance, 49(1), pp. 95-115.

Wenyao, Li. (2007). The Determinants of Cash Holdings: Evidence from Chinese Listed Companies. Available at: http://www.seiofbluemountain.com. 